\title{
Gastrointestinal parasitism of goats in hilly region of Meghalaya, India
}

\author{
Meena Das, R. Laha, A. Goswami and A. Sen \\ Division of Animal Health, ICAR Research Complex for NEH Region, Umiam - 793 103, Meghalaya, India. \\ Corresponding author: Meena Das, e-mail: meenad3@gmail.com, \\ RL: rglaha@gmail.com, AG: dranup15@gmail.com, AS: arnabsen123@gmail.com \\ Received: 25-07-2016, Accepted: 23-12-2016, Published online: 19-01-2017
}

doi: 10.14202/vetworld.2017.81-85 How to cite this article: Das M, Laha R, Goswami A, Sen A (2017) Gastrointestinal parasitism of goats in hilly region of Meghalaya, India, Veterinary World, 10(1): 81-85.

\begin{abstract}
Aim: The aim of this study was to determine the prevalence of gastrointestinal (GI) parasitic infections in goats of hilly region of Meghalaya.

Materials and Methods: A total of 834 fecal samples of goats were screened for 1 year (2014-2015) using flotation techniques.

Results: The overall prevalence of GI parasitic infections in goats was $28.65 \%$. Season-wise highest infections were recorded during rainy season (34.92\%) followed by cool $(26.87 \%)$, hot (26.62\%), and cold (20.39\%) seasons. Helminths and protozoa infections were recorded in $63.60 \%$ and $23.02 \%$ animals, respectively. Among the helminths, Strongyle spp. (32.63\%) was recorded highest followed by Trichuris spp. (12.55\%), Moniezia spp. (10.04\%), and Trichuris spp. (8.36\%). Among protozoa, only Eimeria spp. was detected. Seven different species of Eimeria spp. were identified, viz., Eimeria christenseni, Eimeria hirci, Eimeria caprina, Eimeria jolchijevi, Eimeria ninakohlyakimovae, Eimeria arloingi, and Eimeria kocharii for the first time from Meghalaya. Maximum egg per gram and oocyst per gram of feces were recorded in the month of August (932.4) and September (674.05), respectively. Mixed infections were recorded in $13.38 \%$ samples. Coproculture of goat fecal samples revealed the presence of Haemonchus contortus (72.16\%), Oesophagostomum spp. (14.41\%), Strongyloides spp. (8.91\%), and Trichostrongylus spp. (4.50\%) larvae.
\end{abstract}

Conclusion: This study indicates that GI helminths and protozoa infections are prevalent in goats of this hilly region of Meghalaya, throughout the year and highly prevalent during rainy season.

Keywords: gastrointestinal parasites, goat, helminths, Meghalaya, protozoa.

\section{Introduction}

Domestic goat is among the earliest animals domesticated by man and is distributed worldwide with higher concentrations in tropical areas and in dry zones [1]. Goats are excellent meat producers for human consumption in view of its short generation intervals and the absence of religious taboos associated with their meat as they are rich sources of protein and can help bridge the gap of protein malnutrition among consumers [2]. Gastrointestinal (GI) parasitic infections are common in goats causing considerable economic losses as a consequence of mortality in infected animals and reduced weight gain. Most common GI parasites in goats are helminths and coccidia $[3,4]$. Coccidiosis in small ruminants is caused by a protozoan parasite which belongs to genus Eimeria and often can be seen in small as well as in large intestine [5].

It leads to poor growth rate, diarrhea, dysentery, and anemia and supposed to be one of the

Copyright: Das, et al. Open Access. This article is distributed under the terms of the Creative Commons Attribution 4.0 Internationa License (http://creativecommons.org/licenses/by/4.0/), which permits unrestricted use, distribution, and reproduction in any medium, provided you give appropriate credit to the original author(s) and the source, provide a link to the Creative Commons license, and indicate if changes were made. The Creative Commons Public Domain Dedication waiver (http://creativecommons.org/ publicdomain/zero/1.0/) applies to the data made available in this article, unless otherwise stated. economically most important diseases of small ruminants (sheep and goats) as far as intensive farming is concerned [6]. It is mainly suspected when animals are kept under poor hygienic conditions and the mortality is mainly evident during weaning period [5]. These parasites often lead to destruction of epithelial cells of intestine and interfere with intestinal microflora [7]. 17 Eimeria species have been described in goats [8]. However, only nine Eimeria species could create an infection and the most pathogenic species in goat is E. arloingi [9]. According to Dik [10] and Nourani et al. [11], Eimeria species from goat are also localized in liver, gallbladder, bile ducts, hepatic and mesenteric lymph nodes as well as small and large intestine. E. arloingi causes polyp and nodular hyperplasia in intestinal mucosa [9] and could result in fatal coccidiosis. In goats, the most important species which leads to clinical signs includes E. ninakohlyakimovae and E. arloingi $[12,13]$. Environmental factors also play a vital role in the parasitic infections and the prevalence rate of infections may vary [14]. The disease is mostly transmitted by ingestion of contaminated feed, water, pastures with parasitic eggs, ova, cysts, etc.

Therefore, taking into account the significance of the GI parasites as one of the most important causes of economic losses, the present study was designed to determine the prevalence of GI parasites in goats of hilly region of Meghalaya. 


\section{Materials and Methods}

\section{Ethical approval}

The experiments comply with the guidelines laid down by the Institutional Ethical Committee and in accordance with the country law.

\section{Study area}

The present study was conducted in two districts of Meghalaya, viz., Ri Bhoi and East Khasi Hills. Ri Bhoi district occupies an area of $2378 \mathrm{~km}^{2}$ and lies between $25^{\circ} 15^{\prime}$ and $26^{\circ} 15^{\prime}$ North latitudes and $91^{\circ} 45^{\prime}$ and $92^{\circ} 15^{\prime}$ East longitudes. This district is characterized by rugged and irregular land surface. It includes a series of hill ranges which gradually sloped toward the north and finally joins the Brahmaputra Valley (https:// en.wikipedia.org/wiki/Ri-Bhoi district). East Khasi Hills district forms a central part of Meghalaya and covers a total geographical area of $2748 \mathrm{~km}^{2}$. It lies between $25^{\circ} 07^{\prime}$ and $25^{\circ} 41^{\prime}$ North latitudes and $91^{\circ} 21^{\prime}$ and $92^{\circ} 09^{\prime}$ East longitudes. This district is mostly hilly with deep gorges and ravines on the southern portion (https://en.wikipedia.org/wiki/East_Khasi Hills district). The study area was situated at an altitude of about 600-1800 $\mathrm{m}$ above mean sea level where average monthly minimum and maximum temperature were $6.5^{\circ} \mathrm{C}$ and $30.8^{\circ} \mathrm{C}$, respectively. The average monthly relative humidity prevailed during the study period was $61.6 \%$ (minimum) to $88.9 \%$ (maximum) with average annual total rainfall $2877 \mathrm{~mm}$.

\section{Study period}

The study was conducted for one calendar year from April 2014 to March 2015 and divided into four seasons, viz., hot (March, April), rainy (May, June, July, August, September), cool (October, November), and cold (December, January, February).

\section{Study method}

A total of 834 fecal samples of goats were collected from different places of Ri Bhoi and East Khasi Hills districts of Meghalaya. Fecal samples were collected directly from the rectum of the different animals at monthly intervals. The age of the animals ranged from 2 months to 1 year. All samples were kept in marked plastic pouch/vials. To find out the eggs/ova/ cyst of helminths and protozoa, samples were examined by flotation and sedimentation techniques [15]. Samples not being examined on the same day were preserved and stored at refrigerated temperature $\left(4^{\circ} \mathrm{C}\right)$ for next day examination. The egg per gram (EPG) and oocyst per gram (OPG) of feces were estimated by modified McMaster technique. Fecal samples found positive for Strongyle group of parasites were subjected to coproculture for obtaining third stage infective larvae $\left(\mathrm{L}_{3}\right)$. The pooled fecal samples were finely broken and mixed with sufficient quantity of activated charcoal. The mixture was then packed loosely in glass culture dishes and incubated at $27^{\circ} \mathrm{C}$ for 7 days as per the described procedure in MAFF [15]. The $\mathrm{L}_{3}$ was subsequently harvested and identified according to Borgsteede and Hendriks [16] and Soulsby [17]. Sporulated oocysts of Eimeria spp. were obtained by mixing feces containing oocyst of Eimeria spp. with $2.5 \%$ potassium dichromate solution as per the procedure described by Bhatia [18].

\section{Results and Discussion}

Examinations of fecal samples revealed the prevalence of GI parasitic infections in goats of hilly region of Meghalaya, throughout the year. The overall prevalence of GI parasitic infections in goats was $28.65 \%$. Season-wise highest infections were recorded during rainy season (34.92\%) followed by cool (26.86\%), hot (26.62\%), and cold (20.39\%) seasons (Table-1). Helminths and protozoa infections were recorded in $63.60 \%$ and $23.02 \%$ animals, respectively. Among the helminths, Strongyle spp. (32.63\%) was recorded highest followed by Strongyloides spp. (12.55\%), Moniezia spp. (10.04\%), and Trichuris spp. $(8.36 \%)$. Among protozoa, only Eimeria spp. $(23.02 \%)$ was detected. Month-wise intensity of Strongyle spp. EPG and Eimeria spp. OPG of feces are shown in Figure-1. Maximum and minimum EPG was recorded in the month of August (932.4) and February (208.25), respectively, while maximum and minimum OPG was recorded in the month of September (674.05) and February (118.36), respectively. Mixed infections with more than one species of GI parasites were also recorded in $13.38 \%$ samples. The percent prevalence of different species of GI parasites in goats of Meghalaya was depicted in Figure-2. Coproculture of goat fecal samples revealed the presence of Haemonchus contortus (72.16\%), Oesophagostomum spp. (14.41\%), Strongyloides spp. (8.91\%), and Trichostrongylus spp. (4.50\%) larvae throughout the year (Table-2). Seven different species of Eimeria spp. were identified after examining sporulated oocysts, viz., E. christenseni, E. hirci, E. caprina, E. jolchijevi,

Table-1: Season-wise prevalence of GI parasites in goats of Meghalaya.

\begin{tabular}{|c|c|c|c|c|c|c|c|c|c|}
\hline \multirow[t]{2}{*}{ Season } & \multirow{2}{*}{$\begin{array}{c}\text { Sample } \\
\text { examined }\end{array}$} & \multirow{2}{*}{$\begin{array}{l}\text { Sample } \\
\text { positive }\end{array}$} & \multicolumn{5}{|c|}{ Helminths } & \multirow{2}{*}{$\begin{array}{c}\text { Protozoa } \\
\begin{array}{c}\text { Eimeria } \\
\text { spp. }\end{array}\end{array}$} & \multirow{2}{*}{$\begin{array}{c}\text { Mixed } \\
\text { infection }\end{array}$} \\
\hline & & & $\begin{array}{l}\text { Strongyle } \\
\text { spp. }\end{array}$ & $\begin{array}{c}\text { Strongyloides } \\
\text { spp. }\end{array}$ & $\begin{array}{l}\text { Moniezia } \\
\text { spp. }\end{array}$ & $\begin{array}{l}\text { Trichuris } \\
\text { spp. }\end{array}$ & Overall & & \\
\hline 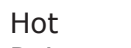 & 139 & $37(26.62)$ & $11(29.73)$ & $5(13.51)$ & $4(10.81)$ & $4(10.81)$ & $24(64.86)$ & $9(24.32)$ & $4(10.81)$ \\
\hline Rainy & 355 & $124(34.93)$ & $45(36.29)$ & $15(12.10)$ & $14(11.29)$ & $8(6.45)$ & $82(66.13)$ & $23(18.55)$ & $19(15.32)$ \\
\hline Cool & 134 & 36 (26.87) & $11(30.55)$ & $5(13.88)$ & $2(5.55)$ & $5(13.88)$ & $23(63.89)$ & $9(25.00)$ & $4(11.11)$ \\
\hline Cold & 206 & 42 (20.39) & $11(26.19)$ & $5(11.90)$ & $4(9.52)$ & $3(7.14)$ & $23(54.76)$ & $14(33.33)$ & $5(11.90)$ \\
\hline Total & 834 & $239(28.65)$ & $78(32.63)$ & $30(12.55)$ & $24(10.04)$ & $20(8.36)$ & $152(63.60)$ & $55(23.02)$ & $32(13.38)$ \\
\hline
\end{tabular}

Figures in parentheses indicates percent positivity. GI = Gastrointestinal 
Table-2: Percent composition of infective larvae in coproculture of goats.

\begin{tabular}{|c|c|c|c|c|}
\hline Month & H. contortus & Oesophagostomum spp. & Strongyloides spp. (4.12\%) & Trichostrongylus spp. (2.70\%) \\
\hline April'14 & 67 & 26 & 4 & 3 \\
\hline May'14 & 68 & 20 & 6 & 6 \\
\hline June'14 & 75 & 11 & 9 & 5 \\
\hline July'14 & 70 & 15 & 12 & 3 \\
\hline Aug'14 & 68 & 10 & 14 & 8 \\
\hline Sept'14 & 72 & 13 & 10 & 5 \\
\hline Oct'14 & 70 & 16 & 13 & 1 \\
\hline Nov'14 & 75 & 9 & 12 & 4 \\
\hline $\mathrm{Dec}^{\prime} 14$ & 78 & 10 & 9 & 3 \\
\hline Jan'15 & 77 & 12 & 4 & 7 \\
\hline Feb'15 & 74 & 17 & 5 & 4 \\
\hline Mar'15 & 72 & 14 & 9 & 5 \\
\hline Total (\%) & $866(72.16)$ & $173(14.41)$ & $107(8.91)$ & $54(4.50)$ \\
\hline
\end{tabular}

H. contortus=Haemonchus contortus

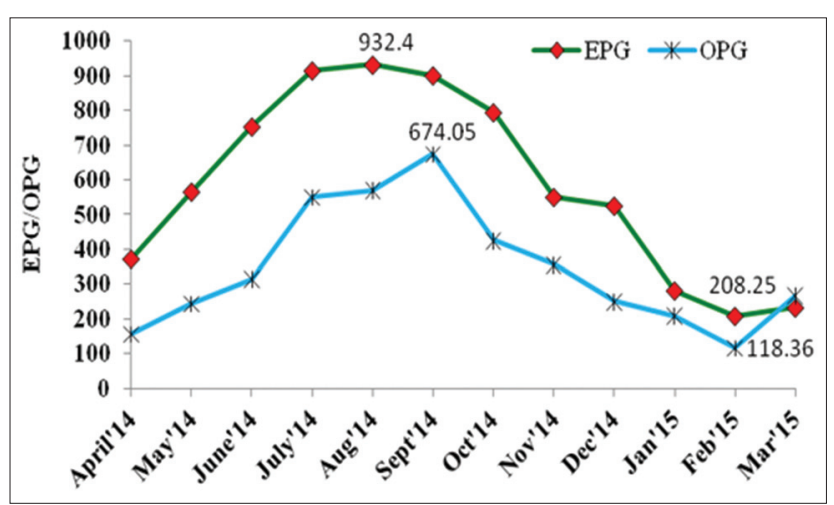

Figure-1: Month-wise intensity of egg per gram and oocyst per gram in goats of Meghalaya.

E. ninakohlyakimovae, E. arloingi, and E. kocharii for the first time from Meghalaya (Figure-3).

In the present study, the prevalence of GI parasitic infections in goats was observed throughout the year. The present finding was in accordance with Olanike et al. [19] and Nwigwe et al. [20] who reported prevalence of helminths and protozoan parasites (Strongyle spp., Strongyloides spp., and Coccidia) in the intestinal tract of goats. After fecal culture, H. contortus has been reported as predominant species in goats of India [14,21]. Besides, H. contortus, Trichostrongylus spp., and Oesophagostomum spp. have been found as the most prevalent species of nematodes in goats [22]. The prevalence of Eimeria spp. (23.02\%) in the present findings is in agreement with the findings of Rehman et al. [23] from Pakistan and Iqbal et al. [24] from Jammu, who reported $55.99 \%$ and $54.42 \%$ Eimeria spp. infection in goats, respectively. 16 species of Eimeria have been recorded from goats in different parts of the world [25,26]. Four species, viz., E. ninakohlyakimovae, E. arloingi, E. caprina, and E. hirci were identified from Pakistan [23]. Two species of coccidia, viz., E. arloingi and E. ninakohlyakimovae in goats have been reported from Assam [27]. However, so far our knowledge is concerned, there is no report on the prevalence of different species of Eimeria in goats of Meghalaya, and this report may be considered as the first report on prevalence of seven species of coccidia of goats, i.e. E. christenseni, E. hirci, E. caprina, E. jolchijevi, E. ninakohlyakimovae, E. arloingi, and E. kocharii from the state Meghalaya. Moreover, Iqbal et al. [24] observed highest infection rate in kids (74.48\%) than adult goats $(33.33 \%)$. The prevalence of Eimeria throughout the year might be due to nonadministration of coccidiostat or coccidicidal drugs by the farmers.

This shows that the climate in this region is exclusively conducive for the development and propagation of parasites. Moreover, the meteorological parameters such as temperature, humidity, and relative humidity are found to be favorable for exogenous development of GI parasites throughout the year in this region. Other factors which might be responsible are constant exposure to infections, continuous deposit of infections on the pastures by adult animals as well as poor animal husbandry practices.

\section{Conclusion}

The present study revealed that there is prevalence of GI helminths and protozoa infections in goats of Meghalaya, throughout the year and highest during rainy season.

\section{Authors' Contributions}

MD and RL: Examined samples and prepared manuscript, AG: Collected, processed and examined samples, AS: Interpretation of data. All authors read and approved the final manuscript.

\section{Acknowledgments}

We are thankful to Indian Council of Agricultural Research (ICAR), New Delhi, for providing financial assistance to carry out this research work under the project "All India Network Programme on GI Parasitism (Institute Code-OXXO1816)." The facilities provided by Director, ICAR Research Complex for NEH Region, Umiam, Meghalaya are thankfully acknowledged.

\section{Competing Interests}

The authors declare that they have no competing interests. 


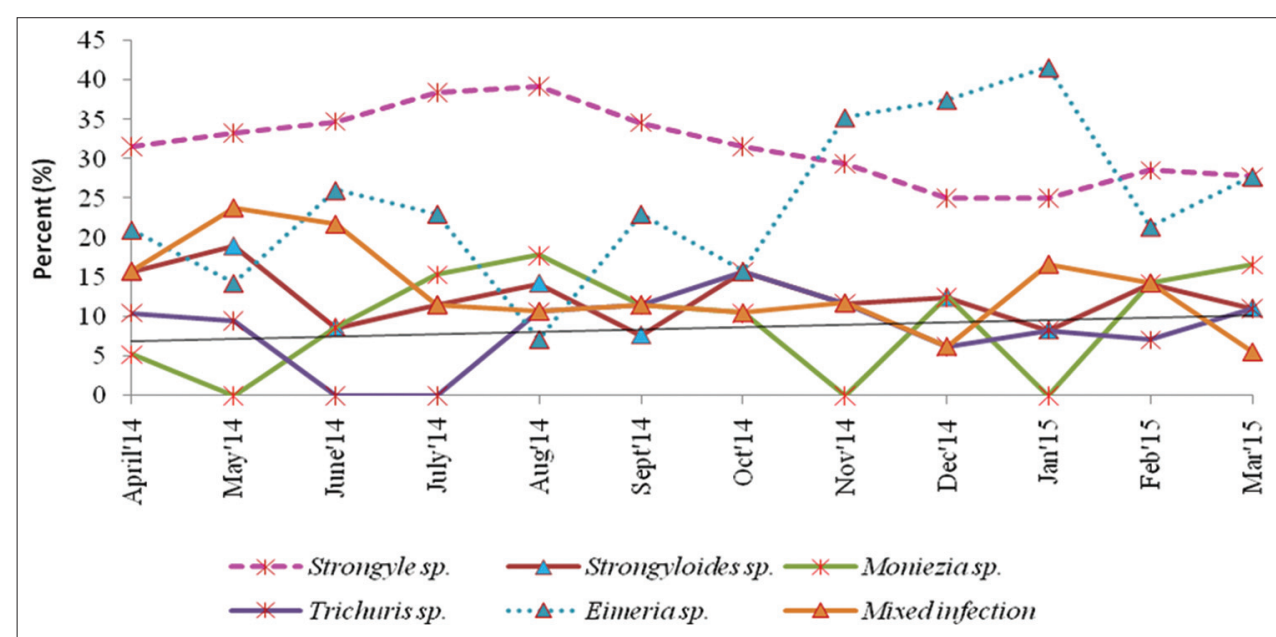

Figure-2: Percent prevalence of different species of gastrointestinal parasites in goats of Meghalaya.

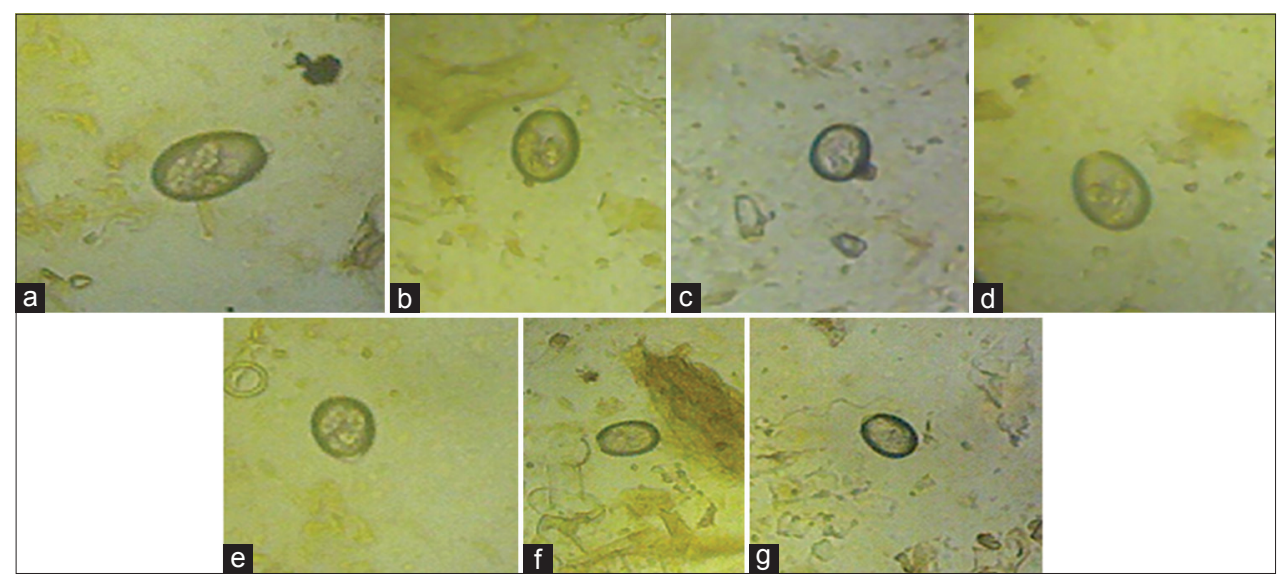

Figure-3: Different species of Eimeria spp. in goats of Meghalaya. (a) Eimeria christenseni, (b) Eimeria jolchijevi, (c) Eimeria ninakohlyakimovae, (d) Eimeria caprina, (e) Eimeria hirci, (f) Eimeria kocharii, (g) Eimeria arloingi.

\section{References}

1. Di Cerbo, A.R., Manfredi, M.T., Zanzani, S. and Stradiotto, K. (2010) Gastrointestinal infection in goat farm in Lombardy (Northern Italy): Analysis on community and spatial distribution of parasites. Small Rumin. Res., 88: $102-112$

2. Maingi, N., Gichanga, E.J. and Gichovi, V.M. (1993) Prevalence of gastro-intestinal helminths and coccidial parasites and frequency distribution of some nematode genera in some farms in four districts in Kenya. Bull. Anim. Health Prod. Afr., 41: 285-290.

3. Ozung, P.O., Nsa, E.E., Ebegbulem, V.N. and Ubua, J.A. (2011) The potentials of small ruminant production in cross river rain forest zone of Nigeria: A review. Cont. J. Anim. Vet. Res., 3(1): 33-37.

4. Waruiru, R.M., Mbuthia, P.G. and Kimoro, C.O. (1993) Prevalence of gastrointestinal parasites and liverflukes in calves in Mathira division of Nyeri District, Kenya. Bull. Anim. Health Prod. Afr., 41: 291-296.

5. Chartier, C. and Paraud, C. (2012) Coccidiosis due to Eimeria in sheep and goats, a review. Small Rumin. Res., 103(1): 84-92.

6. Chhabra, R.C. and Pandey, V.S. (1992) Prevalence of coccidia in sheep in Zimbabwe. Small Rumin. Res., 8: 257-264.

7. Mohammed, R.A., Idris, O.A., El Sanousi, S.M. and Abdelsalam, E.B. (2000) The effect of coccidian infection on the gut microflora of Nubian goat kids. Dtsch. Tierarztl. Wochenschr., 107: 389-428.

8. Dincer, S. and Vatansever, Z. (2001) Koyun ve keçilerde coccidiosis. In: Dincer, S., editor. Coccidiosis. Türkiye
Parazitoloji Derneği Yayınlar No. 17. p219-236.

9. Taylor, M. and Coop, R.L. (2007) Veterinary Parazitology. $3^{\text {rd }}$ ed. Blackwell Publishing, UK. p175-191.

10. Dik, B. (2001) Coccidiosis'de klinik belirtiler. In: Dincer, S., editor. Coccidiosis. Parazitoloji Derneği Yayınları No. 17. p57-66.

11. Nourani, H., Karimi, I. and Azizi, H. (2006) Severe and diffuse nodular hyperplasia of jejenum due to Eimeria species in an Iranian native kid. Pak. J. Biol. Sci., 9(8): 1584-1586.

12. Koudela, B. and Bokova, A. (1998) Coccidiosis in goats in the Czech republic. Vet. Parasitol., 76: 261-267.

13. Yvore, P., Esnault, A. and Naciri, M. (1985) Caprine coccidiosis. Effects of mono or multispecific contamination. Rec. Med. Vet., 161: 347-351.

14. Sharma, D.K., Agrawal, N., Mandal, A., Nigam, P. and Bhusan, S. (2009) Coccidia and gastrointestinal nematode infections in semi-intensively managed Jakhrana goats of semi-arid region of India. Trop. Subtrop. Agroeco., 11: $135-139$.

15. MAFF. (1986) Ministry of Agriculture, Fisheries and Food. Manual of Veterinary Parasitological Techniques. Majesty's Stationery Office, London.

16. Borgsteede, F.H. and Hendriks, J. (1974) Identification of infective larvae of gastrointestinal nematodes in cattle. Tijdschr. Diergeneeskd., 99: 103-113.

17. Soulsby, E.J.L. (1986) Helminths, Arthropods and Protozoa of Domesticated Animals. $7^{\text {th }}$ ed. (ELBS) Bailiere, Toindal, London.

18. Bhatia, B.B. (2000) Textbook of Veterinary Protozoology. Directorate of Information and Publications of Agriculture. ICAR, New Delhi. p345-346. 
19. Olanike, A.O., Olayide, A.J., Oludunsin, F.O., Racheal, A.O. and Japhe, D.W. (2015) prevalence of gastrointestinal parasites of goats in Ibadan, Southwest, Nigeria. World J. Agric. Res., 3(2): 49-51.

20. Nwigwe, J.O., Njoku, O.O., Odikamnoro, O.O. and Uhuo, A.C. (2013) Comparative study of intestinal helminths and protozoa of cattle and goats in Abakaliki metropolis of Ebonyi State, Nigeria. Adv. Appl. Sci. Res., 4(2): 223-227.

21. Laha, R., Das, M. and Goswami, A. (2013) Seasonal dynamics of gastrointestinal parasitic infections and prediction of Haemonchus contortus infections of goats in a subtropical hilly region of north-eastern India. Indian J. Anim. Res., 47(4): 309-314.

22. Dorny, P., Symoens, C., Jalila, A., Vercruysse, J. and Sanib, R. (1995) Strongyle infections in sheep and goats under the traditional husbandry system in peninsular
Malaysia. Vet. Parasitol., 56: 121-136.

23. Rehman, T.U., Khan, M.N., Khan, I.A. and Ahmad, M. (2011) Epidemiology and economic benefits of treating goat coccidiosis. Pak. Vet. J., 31(3): 227-230.

24. Iqbal, A., Wazir, V.S., Katoch, R., Singh, R., Suri, S., Yadav, A. and Najimaana, A. (2012) Prevalence of Eimeria spp. in goats of Jammu region of Jammu and Kashmir State. J. Vet. Parasitol., 26(1): 57-59.

25. Soe, A.K. and Pomroy, W.E. (1992) New species of Eimeria (Apicomplexa: Eimeriidae) from the domesticated goat, Capra Hircus in New Zealand. Syst. Parasitol., 23: 195-202.

26. Zajac, A.M. and Conboy, G.A. (2006) Veterinary Clinical Parasitoloy. Blackwell Publishing, New York, USA. p3-4.

27. Buragohain, B., Phukan, A., Baruah, C.C., Dutta, T.C. and Dutta, P.R. (2013) Prevalence of Coccidiosis in goats of greater Kamrup district of Assam. Indian Vet. J., 90(12): 42-43.

$* * * * * * * *$ 